\title{
Innovation roadmapping: science, technology and innovation to vacuum niche domain movements - Part II
}

\author{
Ciência, tecnologia e inovação para os movimentos de nicho no domínio \\ de vácuo: parte II
}

Aline Araujo Perini1*, Marcio Mattos Borges de Oliveira² ${ }^{2}$, Anderson Zanardi de Freitas

\section{ABSTRACT}

The second paper investigated the organizational innovation system at Nuclear and Energy Research Institute. Introduction: Despite the emerging knowledge-based society, the innovation factor has become increasingly important to achieve the improvement of the human development index (HDI). However, the pursuit of this goal is often hampered by an inadequate understanding of the extent to which innovation mechanisms are being transformed by the globalization of industry 4.0. Methodology: Through a pilot study, data was collected from management reports of 11 managers of research centers over seven years. The inputs and outputs of an innovation system were classified for application of data envelopment analysis (DEA). Results: the DNA atomic model of innovation was developed through the concept model of the innovation tree of mature economies to integrate emerging countries. The capacity of the organizational flow and the interfaces of the relations by analysis of the main components as well as the efficiency index were demonstrated. Originality: It contributes to the formulation of science, technology and innovation indicators (C,T\&I) at Nuclear and Energy Research Institute for public policy disclosure.

Keywords: Emerging markets; Efficiency; Innovation and entrepreneurship.

\section{RESUMO}

No segundo artigo foi investigado o sistema de inovação organizacional no IPEN-CNEN/SP. Introdução: Apesar da emergente sociedade baseada no conhecimento, o fator inovação tem se tornado cada vez mais importante para alcançar a melhoria do índice de desenvolvimento humano (IDH). No entanto a busca desse objetivo é muitas vezes dificultada por um entendimento inadequado da extensão em que os mecanismos de inovação estão sendo transformados pela globalização da indústria 4.0. Metodologia: Por meio de estudo-piloto, compilouse dados de relatórios da administração de 11 gerentes dos centros de pesquisa ao longo de sete anos. Classificaram-se as entradas e as saídas do sistema de inovação para aplicação da análise envoltória de dados (DEA). Resultados: Desenvolveuse o modelo DNA atômico de inovação por meio do modelo da árvore de inovação de economias maduras, para integrar países emergentes. A capacidade do fluxo organizacional e das interfaces das relações por análise dos componentes principais foram demonstrados, bem como o índice de eficiência. Originalidade: Contribui para formulação de indicadores de ciência, tecnologia e inovação (C,T\&l) no IPEN-CNEN/SP para desenvolvimento de políticas públicas.

Palavras-chave: Mercados emergentes; Eficiência; Inovação e empreendedorismo

1. Instituto de Pesquisa Energéticas e Nucleares - São Paulo (SP) - Brazil.

2.Universidade de São Paulo - Faculdade de Economia e Administração de Ribeirão Preto - Ribeirão Preto (SP) - Brazil.

Correspondence author: alineperini@yahoo.com

Received: 02/12/2019 Approved: 30/01/2020 


\section{INTRODUCTION}

The objective of this study was to map technical competences and innovative capacities at business level model, in order to produce an innovation roadmap, which aims to contribute to the scientific development of management practices and the elaboration of science, technology \& innovation (S,T\&I) indicators at Instituto de Pesquisas Energéticas e Nucleares of Comissão Nacional de Energia Nuclear (IPEN-CNEN).

The start position that design this paper was due to two critical profiles of manager view from Technology Transference Office (TTO): First, due to internal development process in assessment potential technologies to innovation policies at institutional level, and second, the poor performance of launched patents that remain stored over five years with no commercialization.

In contrast to the development of potential technologies in that region, this study aims at a change of cultural approach in the knowledge pool in the application of methodological building blocks to become a necessary system and share a common language and understanding of the main terms.

The methodology used with high demands of the interactive market with an example of praxis that contributes to fill the gaps in the theory and practice of S,T\&I management adequate to address the eco-responsiveness in regular growth, economic development and yield employment.

\section{Research background}

Big data and analytics have climbed to the top of organizational agenda - for a rationale reason, more structured based informed decision and efficiency of scarce resources like money, people and technology. This implies that organizations that focus on big decisions where better data and models improves outcomes in a transformation leading.

Managers also lead with high complexity due to waves of technological transformation to perdure organizations over time. Bughin ${ }^{1}$ cites examples from the digital industry, narrowing leading data projects to provide better internet services, TV broadcasting and information services, which are respectively Google, Facebook and Netflix.

Traditional companies, however, were related to adapting the success of early users to survive in a complex and competitive environment. Regarding the lack of scientific big data analytics to assess the organizational performance of big data and analytics, Bughin ${ }^{1}$ performed a more systematic, larger-scale and statistical-driven study as to whether or not big data investment has led to an improvement of a company performance trajectory.

A total of 1,500 Telecom, high-tech and financial services companies worldwide are the most representative in Bughin's sample $^{1}$. The author investigated whether the performance of companies has triggered big data projects with better performance than peer companies. Bughin ${ }^{1}$ found that companies that invest in big-data linkage in three major business domains (namely, customer interface, company supply chain and competitors) enabled a performance of about $5.9 \%$, in which the primally cause was attributed of investments in labor and information technology architecture.

Bughin ${ }^{1}$ has affirmed for those early adopter companies that the productive difference was $2.5 \%$ in relation to their peers. Bughin $^{1}$ found that big-data projects targeting customers and competitive intelligence domains bring slightly more performance than big-data projects aimed at supply-chain improvements.

In order to establish an institutional business innovation roadmap, it was necessary to analyze what should then be converted into a coherent action plan at business level. There is not a golden rule, however the negligence the market side while overemphasizing product and technology found often in technology entrepreneurs or the disregard of opportunities provided by new technologies found regularly in marketfocused or more traditional pool of route of success ${ }^{2,3}$.

The holistic analysis intent the provides the fully align with the business strategic challenges and priorities. The intention is to incorporate more structure in innovation activities and tools than to address intelligent systems, and also the contribution of a variety of stakeholders from different organizations and disciplines ${ }^{4}$.

Figure 1 shows the "Object-Subject" approach model, which was classified by the Oslo Manual ${ }^{5}$ as a "specific object project approach" as an example for the development of a specific new product at engineering project level while "subject approach" refers to as organization and business level, that includes either the role company, a joint-venture, or a part of a new design organizational department. The interaction between innovation object and subject explains the innovation strength of small and medium enterprises (SMEs) like their well-known high adaptability.

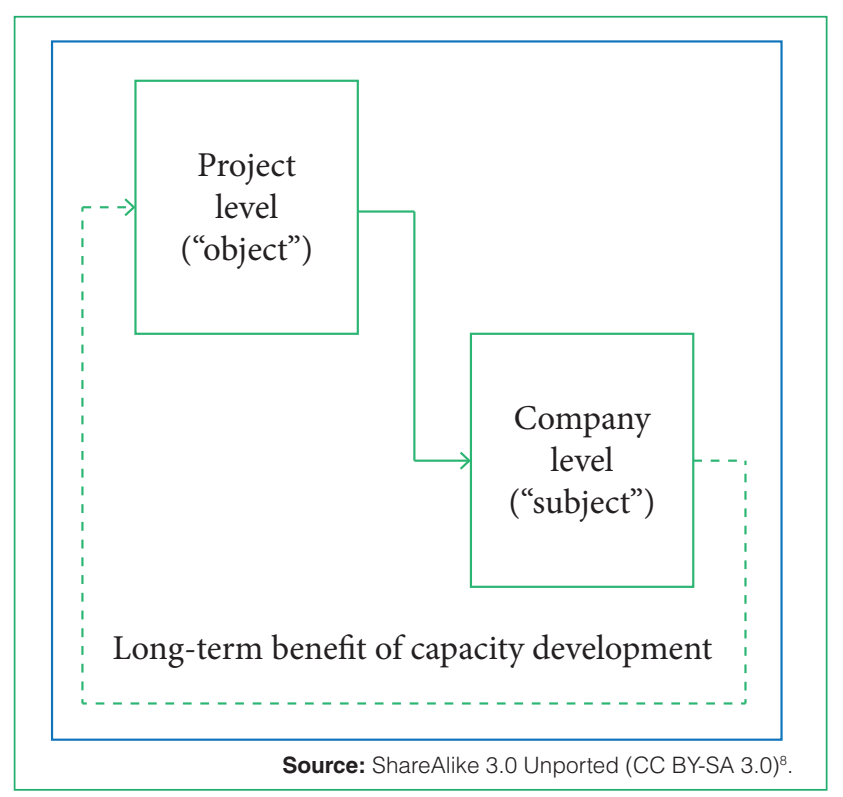

Figure 1: The innovation process in a "object-subject" approach. 
The business model roadmapping interface promotes a long-term benefit of learning cycle and mutual development capacity to taking-up more challenges and more complex environment in a wider context ${ }^{6}$. Here a parallel can be traced from Downes and Nunes when they refer to even more shorter cycles in learning and economics mechanism ${ }^{7}$.

The smE-MPOWER ${ }^{8}$ tool roadmap methodology has been adopted by several European countries which are considering the option to introducing a coaching scheme for SMEs in order to improve their schemas like an appropriate response to these market failures under subsidized public or private funds. The smE-MPOWER ${ }^{8}$ package intend to support innovation needs, aiming ultimately enhance growth, create jobs and boost competitiveness.

Roadmaps can cover a tremendous "dynamic range" in terms of scale and complexity of systems. They also present a linked analysis for a graded taxonomy underpinned the roadmap building. They provide a condensed visual format, incorporating all key perspectives. Roadmapping, as a core competence at business level, was deployed via principles of the business innovation tree model (Fig. 2).

Business level innovation is defined: a creation of significant added value for the costumer and the company through modification of one of the four vectors9. The main four innovation vectors, according to Fig. 2, were characterized as: i) offering, ii) process, iii) distribution and iv) customer that depends of availability of root resources such as: i) source of ideas, ii) internal resources, and iii) partnerships and cooperation. It was possible to observe that quality of its sources mirrors the vectors balance innovation.

To deal with innovation challenges towards an effective growth, economic development and yield employment in the environment it is necessary to hydrate. The push and/or pull innovation lens assumed "market-driven" and/or "SME adapted" in "market-driven", the roadmap, such as core competence, fits currently lacking of capabilities and precise interventions like to hydrate, to feed or natural interferences on supporting innovation management, proper to the level importance of a cycle-stage of

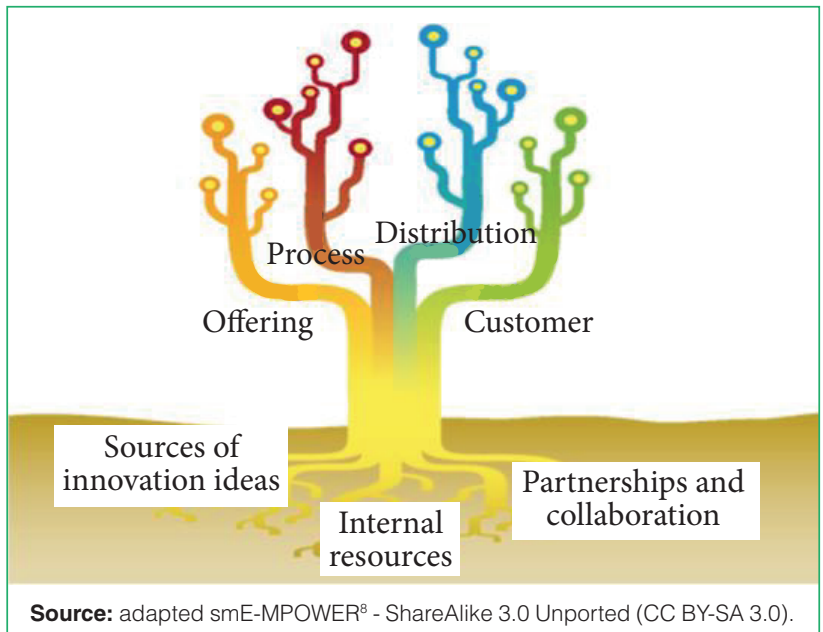

Figure 2: Business innovation tree model. a firm and preparation level or strength of capabilities in this area. In "SME adapted", the higher the chance that company will take action following the intervention and apply this newly fund knowledge, accomplishment with learn cycle and symbiotic relationship over time.

Rural innovation on the ground regarding its seed origin and aims smart specialization on geographical economy and supportive hydrous framework of emerging regional experiences. In particular, a study performed by Pires et al. ${ }^{10}$ related that rural dimension of innovation has often remained neglected, affecting its contribution to economic growth and regional development to rural resources and actors.

\section{Objectives}

To characterize IPEN-CNEN/SP innovation system to auto-roadmap discovery. The specific objectives lay on the establishment of a gravitational field for S,T\&I for smart cities solution, the outline of the DNA atomic innovation eco-system of IPEN-CNEN/SP to covering business, technology and intellectual properties policies for developing countries.

\section{METHODOLOGY}

The data envelopment analysis (DEA) technique consist of a roadmap of IPEN-CNEN/SP innovation business activities. There are two main models: i) CCR model oriented to inputs with the effect of optimizing capacity and constant returns as a result; ii) Output-oriented BCC model, with the effect of returning increasing variable scales ${ }^{11,12}$.

Using the DEA technique processing data available in the IPEN-CNEN/SP Master Plan from 2012 to 2018, a GovernmentUniversity-Industry (G-U-I) as a proxy for principal components was applied, distributing and classifying information for every 11 research centers over past seven years. After two audits of compiled data, it was consolidated in Excel spreadsheet using data analysis and function optimization supplements. Scattering plot was performed, expressing the linear function of production system, as well as its regression coefficient $\mathrm{R}$ and its determinant $\mathrm{R}^{2,13}$.

The DEA analysis needed to be compared by another similar population; each illustration year was used as a unit of analysis or decision-making unit (DMU). Sequentially, the DEA line boundary was plotted on the scatter plot covering every point expressed. Finally, the consolidated results were distributed to the main G-U-I components and the calculation of the efficiency indices was found.

According to DEA technique (Fig. 3), the tree innovation model (Fig. 2) was transformed into a light box of prism lens. From this perspective, the inputs were classified into partnerships and collaborations, patents, papers, human resources and projects of development. The outputs were classified in $\operatorname{SME}(\mathrm{s})$ projects, quality index publication, licensed patents, citations of author, funded students and concluded M.Sc. and Ph.D. 
The DEA model carried out in IPEN-CNEN/SP presupposes the symmetry of the analysis of the resources consumed (inputs) and the results obtained (outputs): the relations are equal ${ }^{2,3}$. The trial elements that compose inputs and outputs derivates from studies in innovation, economics, accountability and legal law $^{14-16}$. Evaluating the current status of this study, the application was classified into essential characteristics for the efficiency of the innovation system: to identify current activities and existing patterns of innovation efficiency.

Figure 4 introduces a pilot result from Research Reactor Research Center (1) and the Nuclear Engineering Research Center (2). The gathering reached into four dimensions: human resources

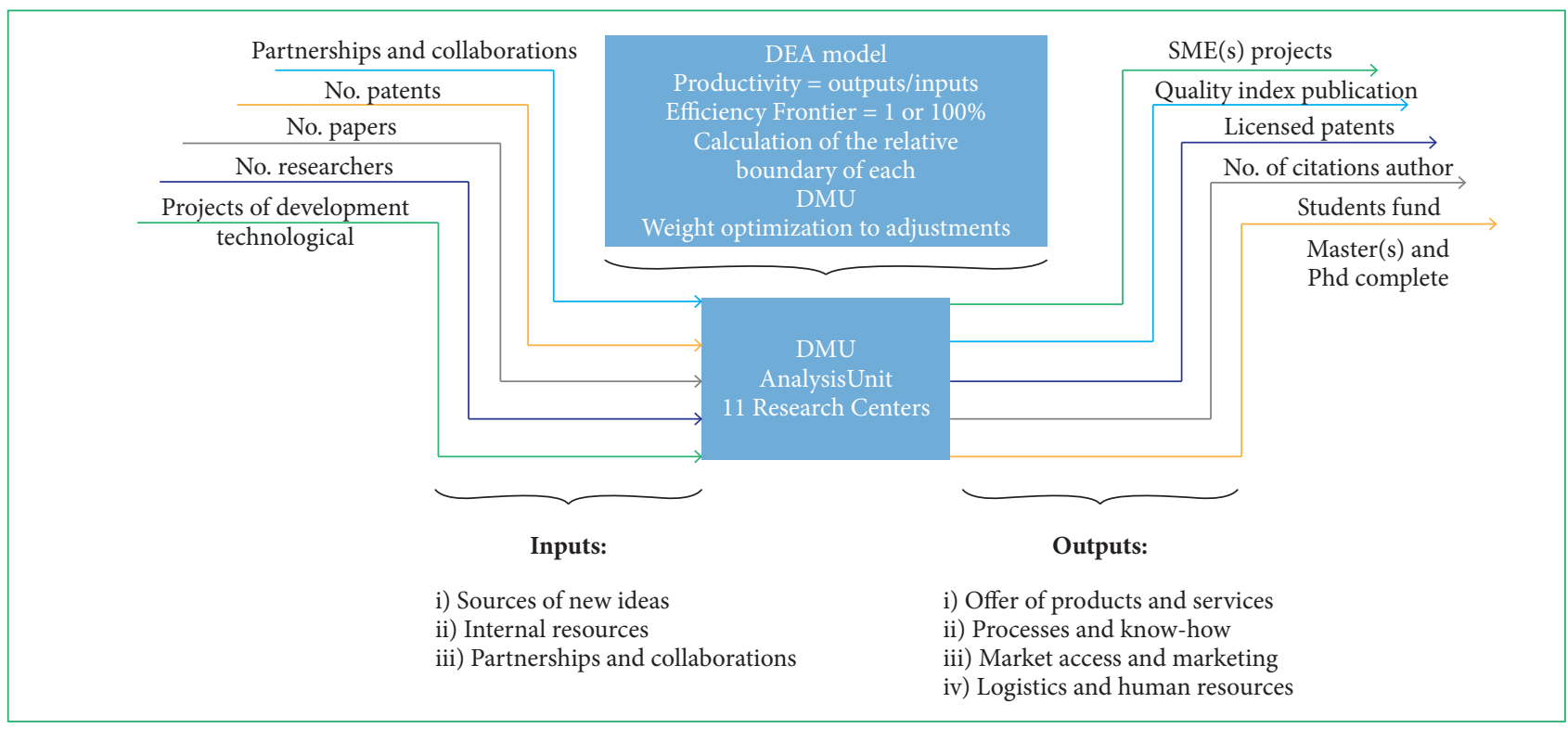

Figure 3: DEA adapted technique.

\section{(a) Human resources}

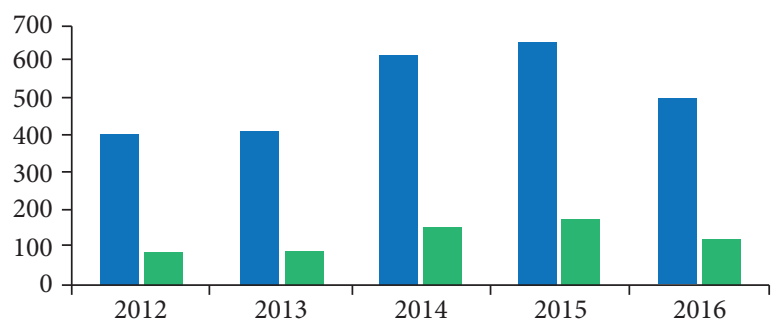

- Pars on Collaborations and Cooperations

- Total Nuclear and Energy Research Institute (CNEN-IPEN-SP) and Pars

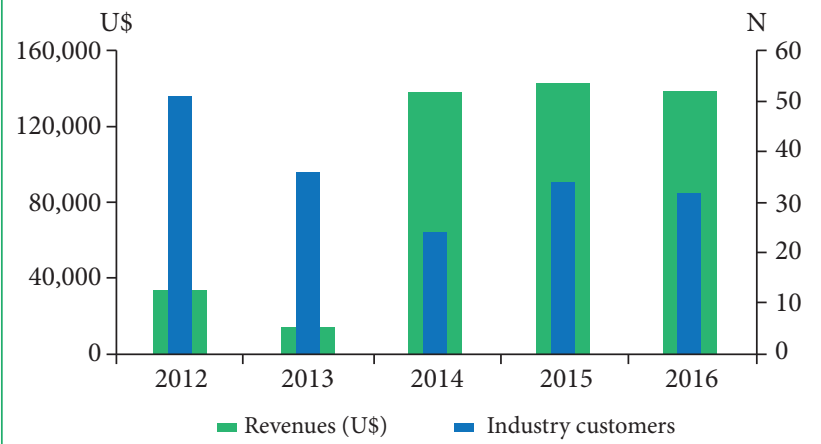

(b) Teach \& education

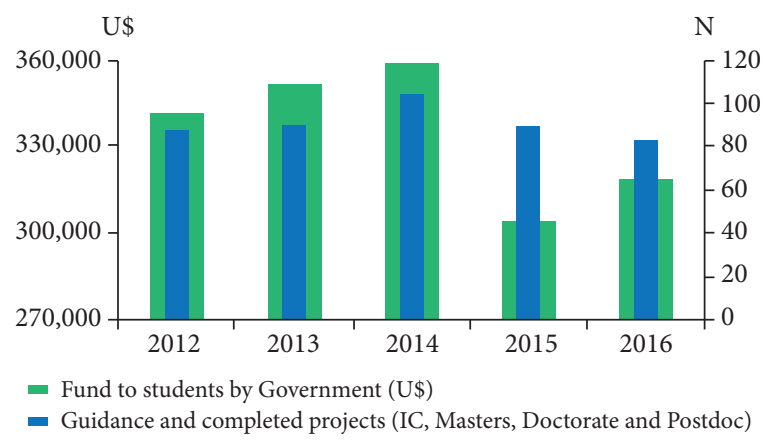

(d) Scientific \& technological

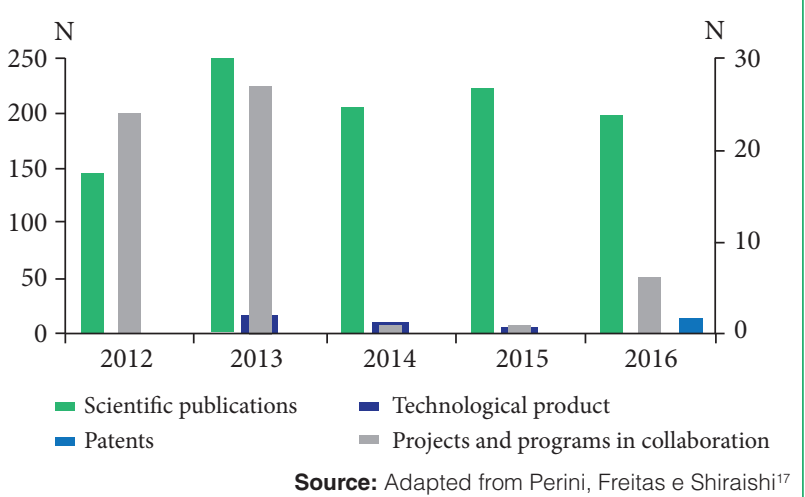

Figure 4: Pilot result from Research Reactor Research Center and the Nuclear Engineering Research Center. 
(Fig. 4a), teaching and education (Fig. 4b), goods and services (Fig. 4c), science and technology (Fig. 4d). The collaboration and cooperation of the workforce can be highlighted. This effect is most intense in 2014, 2015 and 2016.

Figure $4 \mathrm{~b}$ displays data visualization of teaching and education that contain total amount funded to students by the government and total amount of concluded projects of scientific research.

Figure $4 \mathrm{c}$ shows the product and service data visualization that contains the total revenues in US dollars and the total number $(\mathrm{N})$ of customers for the two research centers.

Figure $4 \mathrm{~d}$ shows data visualization of scientific and technological dimensions. The major contribution came from number of scientific publications, projects and programs. Number of technological products and number of patents complete the results.

This work covers all 11 research centers over 7 years, from 2012 to 2018 , in order to explain the technological suitability of the innovation responsible for the research (RRI) ${ }^{18}$ with the scientific literature and its improvements in the treatment of inputs and outputs in the total innovation system of the Brazilian Nuclear and Energy Research Institute (IPEN-CNEN/ SP).

\section{RESULTS AND ANALYSIS}

The Technology Transference Office (TTO) of IPEN-CNEN/SP was created in 2014 based on the Innovation Law n. 10,973. The TTO function is to coordinate the innovation activities of the institute, so TTO is hierarchically organized above the 11 research centers.

Nuclear and nanotechnology have applications in several industries such as security, agriculture for food and nutrition, health for radiopharmaceuticals, cancer diagnosis and treatment, metalworking industry for the oil industry or energy for Angra I and Angra II, and nuclear plants located in the State of Rio de Janeiro. The DNA atomic innovation ecosystem is demonstrated in Fig. 5.

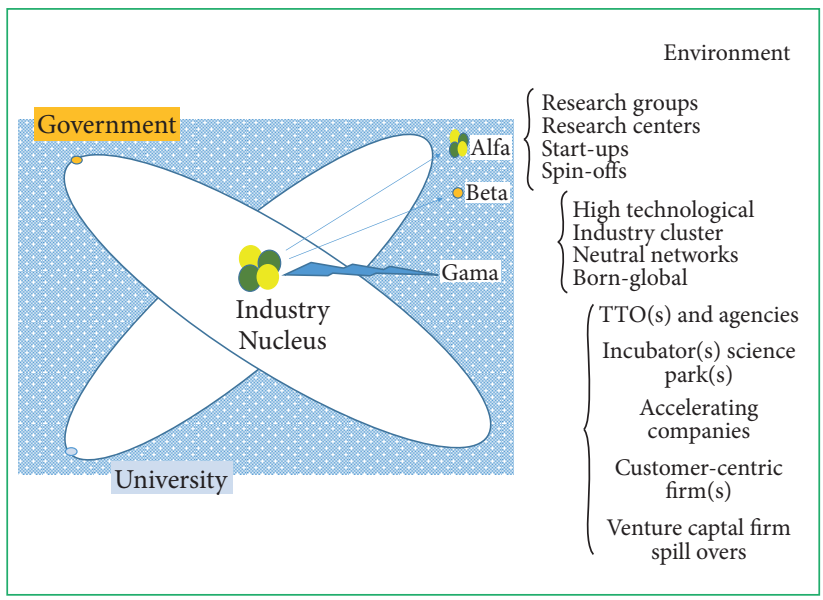

Figure 5: DNA atomic innovation eco-system of IPEN-CNEN/SP.
Figure 6 presents the DEA frontiers along 2012 to 2018. The abscissa $x$ represents inputs, and images ordered on axis $y$ represent outputs. A quadrant bisector is a line with an end at the point $(0,0)$, which divides the angle into two congruent angles. The determination coefficient was negative $\mathrm{R}^{2}=-0.328$, and correlation coefficient $|\mathrm{R}=0.5727|$. The linear regression line was expressed in equation (1) $\mathrm{y}=1.4905 \mathrm{x}$

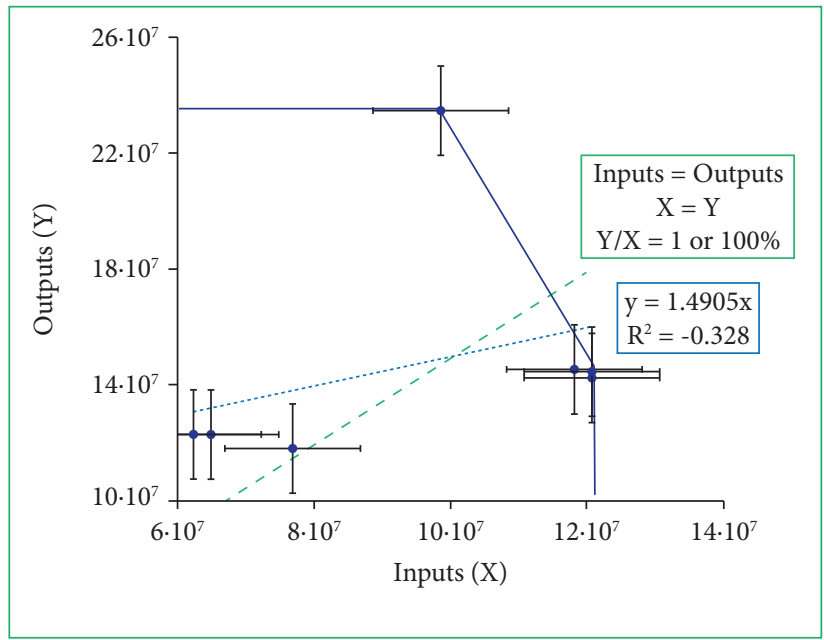

Figure 6: DEA business model frontier of IPEN-CNEN/SP.

Figure 7 shows a panorama of results of total data visualization from innovation system at Nuclear and Energy Research Institute (IPEN-CNEN / SP), which encompasses the activities of all 11 research centers. Figure 7a shows data visualization of organizational volume capacity flow from 2012 to 2018 cycle. It was possible to highlight that the flow of organizational capacity is increased throughout the cycle. The assumption in Fig. 7 refers to the DEA model mixed at the organizational level, with previous focus on i) input oriented CCR model with the effect of optimizing capacity and constant returns as a result; and last especially in 2018 focus on ii) output-oriented BCC model with the effect of returning increasing variable scales.

Figure $7 \mathrm{~b}$ shows data visualization of composed percentage amount of inputs and outputs, which also demonstrates the efficiency index from 2014 to 2018, where it reached the highest peak of the curve, especially in 2018. For 2015, 2016 and 2017 the efficiency remained approximately 1 , regarding symmetry of relationships between the inputs and outputs elements.

Figure $7 \mathrm{c}$ shows data visualization of organizational inputs and outputs volume capacity difference. The volume capacity outputs were always higher than inputs along this cycle. Also, the outputs stability was higher than inputs, except in 2018.

Figure $7 \mathrm{~d}$ shows Paretto outputs. The evidence of mixed DEA model at organizational level was confirmed. From 2012 to 2017, the organizational focus on i) CCR model oriented to inputs with the effect of optimizing capacity and constant returns as a result; at 2018 focus on ii) output-oriented BCC model, with the effect of returning increasing variable scales. 


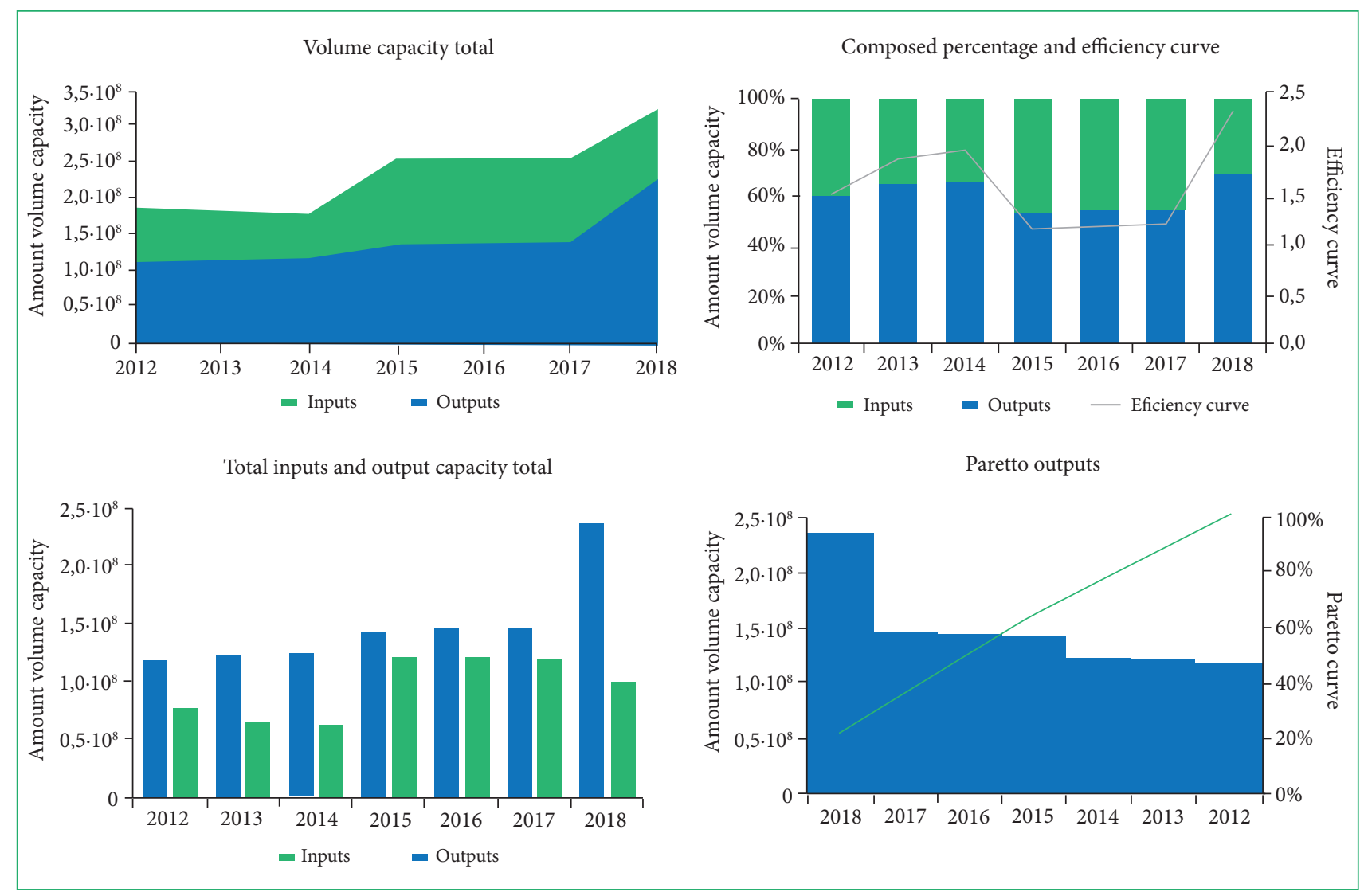

Figure 7: Panorama of results of total data visualization from innovation system at Nuclear and Energy Research Institute.

Table 1 highlights the flow capacity of the relationships between the protagonists of the government, industry and university (G-U-I) of technology transfer system as well as the calculation of each efficiency. It covers the seven past years flow interactions and demonstrates the size of inputs and outputs with interfaces. The total efficiency of the intelligent specialization fund was $156 \%$, which emerges from the assumptions of the outputoriented model of the BCC, with the effect of returning increasing variable scales. Efficiency was predominantly the highlight of the interface with the industry. The government is the master key that catalyzes the production of a new propeller fund for intelligent eco-specialization.

Table 1: Efficiency distribution of interactions flow of IPEN-CNEN/SP.

\begin{tabular}{c|c|c|c|}
\hline $\begin{array}{c}\text { Efficiency } \\
\text { analysis }\end{array}$ & Output & Input & Efficiency \\
\hline Government & $72,211,434$ & $662,430,631$ & $11 \%$ \\
\hline Industry & $918,043,296$ & 1,858 & $49,410,296 \%$ \\
University & $40,524,807$ & 4,607 & $879,635 \%$ \\
\hline Total & $1,030,779,537$ & $662,437,096$ & $156 \%$ \\
\hline
\end{tabular}

\section{CONCLUSION}

The technology transfer system is not linear. Among the TTOs skills to leverage business development and smart ecosystem specialization for regular growth, economic development and employment creation, the self-discovery of roadmapping is a milestone in developing organizational competences to meet the challenges of developing countries to create relationships, partnership, alliances, cooperation and different forms of social interactions to overcome input barriers focus on the research innovation system (RIS).

The IPEN-CNEN/SP DNA atomic innovation ecosystem encompasses mature and emerging economies and provides greater adaptability to institutional capacities to normalize growth in emerging countries in order to build smart innovation specialization links of localized flags to overcome barriers and instabilities to achieve organizational objectives.

The DNA atomic innovation ecosystem of the IPEN-CNEN/ SP model provides the interface and interaction with social actors such as government, university, industry (G-U-I). The DNA atomic innovation ecosystem model also interacts with the organizational research system responsible for innovation (RRIS) for both, i) engineering activities in product design and $R \& D$ and ii) the organizational innovation system.

The previous organizational analysis of the DEA model detected an assumption of i) input oriented CCR model with the effect of optimizing capacity and constant returns as a result. However, in 2018 it was focused on ii) output-oriented BCC model with the effect of returning scales of increasing variables. 
This paper observes the importance in the self-discovery of institutional roadmapping at the enterprise level for communication, learning, dissemination and efficient development and competitiveness for organizations and social function over time. The integration interfaces from the perspective of the social marketing actor extend new competences in the $\mathrm{S}, \mathrm{T}$ \& I system.

\section{ACKNOWLEDGMENTS}

The authors thank CAPES for financing this study, IPENCNEN/SP for the facilities system and trust, and the University of São Paulo for the author's education.

\section{REFERENCES}

1. Bughin J. Big data, Big bang? J Big Data. 2016;3(2):1-14. https:// doi.org/10.1186/s40537-015-0014-3

2. Arundel A, Bloch C, Fergunson B. Advancing innovation in the public sector: aligning innovation measurement with policy goals. Res Policy. 2019;48(3):789-98. https://doi.org/10.1016/j. respol.2018.12.001

3. Simonse LWL, Hultink EJ, Buijs JA. Innovation roadmapping: building concepts from practitioners' insights. J Prod Innov Manag. 2015;32(6):904-924. http://doi.org/10.1111/jpim.12208

4. Ho J-Y, O'Sullivan E. Strategic standardisation of smart systems: A roadmapping process in support of innovation. Technol Forecast Soc Change. 2017;115:301-12. https://doi.org/10.1016/j. techfore.2016.04.014

5. Organization for Economic Co-operation and Development (OCDE); European Statistical (Eurostat). The Measurement of scientific, technological and innovation activities. Oslo Manual: guidelines for collecting, reporting and using data on innovation. 4th ed. Paris: OCDE. 2018. https://doi. org/10.1787/9789264304604-en

6. Senge PM. The leader's new work: building leaning organizations. MIT Sloan Manag Rev. 1990;32(1):7-23.

7. Downes L, Nunes P. Big Bang disruption. Harv Bus Rev. 2013:44-56.s
8. mE-MPOWER Community, Rood Map Tool, 2016. Switzerland [Access: 2020 Jan 25]. Available at: https://ec.europa.eu/easme/ sites/easme-site/files/680936_design_option_paper_on_smempower.pdf.

9. Sawhney SM, Wolcott RC, Arroniz I. The 12 different ways for companies to innovate. MIT Sloan Manag Rev [Internet]. 2006;47(3). [Access: 2020 Jan 25]. Available at: https:/ sloanreview.mit.edu/article/the-different-ways-for-companies-toinnovate/

10. Pertoldi M, Hegyi FB, Pires AR, Edwards J. Smart specialisation and innovation in rural areas. EU Science Hub. 2014;2040(9):1 19. https://doi.org/10.2791/13227

11. Farrel MJ. The measurement of productive efficiency. खJ Roya Stat Soc. 1957;120(3):253-90. https://doi.org/10.2307/2343100

12. Banker RD, Charnes A, Cooper WW. Some models for estimating technical and scale inefficiencies in data envelopment analysis. Manage Sci. 1984;30(9):1078-92. https://doi.org/10.1287/mnsc.30.9.1078

13. Martins MEG. Coeficiente de correlação amostral. Rev Ciência Elem. 2014;2(2):34-35. http://doi.org/10.24927/rce2014.042

14. Perini A, Picarte R. Marketing de Eventos: avaliação da marca da Festa Literária FLIPORTO: proposta de um modelo de análise de eficiência. Latvia: Novas Edições Acadêmicas. 2019.

15. Kemsa D. An investor's perspective on marketing excellence: how objective marketing indicants can complement firm valuations. Wiesbaden: Springer Gabler. 2019. https://doi. org/10.1007/978-3-658-24704-1

16. Abu-Tair A, Lahrech A, Marri K, Hijleh-Abu B (eds) Proceedings of the II International Triple Helix Summit. THS: International Triple Helix Summit. Cham: Springer. 2020 https://doi.org/10.1007/978-3-030-23898-8

17. Perini AA, Shiraishi GF, Freitas AZ. Matching Technological bid in smart cities initiatives: a case study of innovation fairs at research institute in brazil. 27th International Conference on Management of Technology: Towards Sustainable Technologies and Innovation. Birmingham: Aston University. 2018 [Access: 2020 Jan 25]. Available at: http://200.136.52.103/ handle/123456789/29748

18. Aline PA, Marcio OBM, Anderson FZ, Guilherme PA. Structure of value of market-based assets: customers as tangible and intangible assets in the constitution of fourth-helix models. ETHAC - European Triple Helix Congress: Responsible Innovation \& Entrepreneurship. Thessaloniki. 2019. 